$\begin{array}{ccc}\text { Tersedia online di: http://ejournal-balitbang.kkp.go.id/index.php/jppi } & \begin{array}{l}\text { JURNAL } \\ \text { PENELITIAN } \\ \text { PERIKANAN } \\ \text { INDONESIA }\end{array} \\ \text { JURNAL PENELITIANPERI.puslitbangkan@ @gmail.com } & \text { Volume 25 Nomor 1 Maret 2019 } \\ \text { p-ISSN: 0853-5884 } \\ \text { e-ISSN: 2502-6542 }\end{array}$

\title{
DINAMIKA POPULASI DAN TINGKAT PEMANFAATAN KEPITING MERAH (Scylla olivacea) DI PERAIRAN MERAUKE DAN SEKITARNYA, PAPUA
}

\section{POPULATION DYNAMIC AND EXPLOITATION LEVEL OF RED MUD CRAB (Scylla Olivacea) IN MERAUKE AND ITS ADJACENT WATERS, PAPUA}

\author{
Andina Ramadhani Putri Pane ${ }^{\star 1}$ dan Reza Alnanda ${ }^{1}$ \\ 'Balai Riset Perikanan Laut, Kompl. Raiser JI. Raya Bogor KM. 47 Nanggewer Mekar, Cibinong, Bogor, Indonesia \\ Teregistrasi I tanggal: 20 Januari 2019; Diterima setelah perbaikan tanggal: 16 Juli 2019; \\ Disetujui terbit tanggal: 17 Juli 2019
}

\begin{abstract}
ABSTRAK
Penangkapan kepiting merah (Scylla olivacea) di Merauke berlangsung sangat intensif dan dikuatirkan akan mengancam kelestariannya. Pengelolaan yang baik diperlukan untuk manjamin manfaat jangka panjang yang hasil kajian ilmiah seperti dinamika populasi dan tingkat pemanfaatan. Tujuan penelitian ini adalah untuk mengetahui dinamika populasi dan tingkat pemanfaatan kepiting merah di Merauke dan sekitarnya. Penelitian dilakukan selama 2 (dua) tahun yaitu Februari hingga Desember 2017 dan Maret hingga Desember 2018 dengan metode survey. Hasil penelitian menunjukkan struktur ukuran kepiting merah dominan berukuran dibawah $145 \mathrm{mmCW}$ (99\%). Ukuran pertama kali tertangkap (CWc) pada tahun 2017 dan 2018 berturutturut sebesar $110,52 \mathrm{mmCW}$ dan $112,5 \mathrm{mmCW}$. Pola pertumbuhan kepiting merah bersifat allometrik negatif dengan nisbah kelamin tidak seimbang antara jantan dan betina. Laju pertumbuhan $(\mathrm{K})$ adalah 0,6 per tahun dengan tingkat kematian alamiah (M) lebih kecil daripada kematian karena penangkapan (F). Tingkat pemanfaatan (E) 0,68 menjadi indikasi telah terjadi overfishing dari nilai optimum penangkapan kepiting. Upaya pelestarian sumberdaya kepiting dapat dilakukan dengan mengurangi upaya penangkapan sebesar $36 \%$ dari yang sudah dilakukan saat ini.
\end{abstract}

Kata Kunci : Dinamika populasi, tingkat pemanfaatan, kepiting merah, Merauke, WPP NRI 718

\begin{abstract}
Fishing for red mud crabs (Scylla olivacea) in Merauke is very intensive and threat its sustainability. A proper management requires to ensure long term benefits that based on scientific findings, such as population dynamics and exploitation rates. This research to determine population dynamics and exploitation of red mud crabs in Merauke and its adjacent. The study was conducted for 2 (two) years, February to December 2017 and March to December 2018. The results showed that the structure of the size of red mud crabs dominated by under $145 \mathrm{~mm}$ carapace width (99\%). The first size caught (CWc) in 2017 and 2018 were $110.52 \mathrm{mmCW}$ and $112.5 \mathrm{~mm}$ respectively. The growth pattern of red mud crabs was allometric negative with an unbalanced sex ratio between male and female. The growth rate $(K)$ was 0.6 per year while a natural mortality rate $(M)$ is smaller than fishing mortality (F). The utilization rate $(E)$ was 0.68 that indicates an overfishing of the optimum value. To ensure sustainabilitry of the resources, fishing efforts should reduce by $36 \%$ from actual level.
\end{abstract}

Keywords: Population dynamic, explotation level, red mud crabs, Merauke, FMA 718 


\section{PENDAHULUAN}

Komoditas hasil perikanan di Indonesia melimpah baik ikan, udang dan krustasea lainnya seperti lobster, rajungan dan kepiting. Kepiting dominan diperdagangkan dalam kondisi hidup karena nilai jual yang lebih tinggi dan dipasarkan hingga keluar negeri. Kandungan gizi tinggi dan rasa yang enak menjadikan kepiting banyak diminati masyarakat (Herliany \& Zamdial, 2015). Kepiting bakau ada beberapa jenis yaitu Scylla serrata, S. tranquebarica, S. olivacea dan S. Paramamosain (Keenan et al., 1998). Di Indonesia kepiting bakau dominan masih diperoleh dari penangkapan di alam yaitu sebesar $61,1 \%$ dan sisanya dari budidaya pembesaran dan penggemukan (Diantoro \& Pribadi, 2017). Jenis kepiting Scylla olivacea yang paling diminati dalam budidaya karena potensial dan mempunyai daya tahan tubuh yang kuat (Karim, 2008; Waiho et al., 2015).

Habitat hidup kepiting bakau adalah daerah estuaria (Le Vay, 2001; Nontji, 2007) dan hutan mangrove yang masih baik kondisinya (Tahmid, 2015a). Di Indonesia, kepiting bakau hidup di wilayah pesisir dengan mangrove mulai dari Sumatera sampai dengan Papua (La Sara, 2010). Propinsi Papua memiliki hutan mangrove seluas 1.009.692,80 Ha dan sebagian besar tersebar di kabupaten Merauke (31,99\%), Asmat $(29,57 \%)$ dan Mimika (26,01\%) (Dinas Lingkungan Hidup Propinsi Papua, 2018). Namun dalam periode 2000 hingga 2010, hutan mangrove di Kabupaten Merauke telah mengalami penurunan sebesar $45,78 \%$ dari 343.766 Ha menjadi 186.388 Ha (Wibisono, 2013). Wilayah hutan mangrove di Merauke ini masih mempunyai Indeks Nilai Penting (INP) yang tinggi seperti di Distrik Nasem dan Distrik Payum (Masiyah \& Arifin, 2016) serta mempunyai tingkat kerapatan mangrove padat dan baik di wilayah Karang Indah namun rusak di wilayah Samkai dan Rimba Jaya (Masiyah \& Sunarni, 2015). Luasan hutan mangrove tertinggi di Kampung Kumbe Distrik Semangga yaitu 72,25 Ha dengan kondisi baik serta kecil kerusakan (Masiyah, 2016).

Sumberdaya kepiting di Wilayah Pengelolaan Penelitian 718 Laut Arafura termasuk pesisir Merauke berdasarkan KEPMEN KP Nomor 50 Tahun 2017 mempunyai nilai potensi yaitu sebesar 1.498 Ton dengan jumlah tangkapan yang diperbolehkan (JTB) 1.198 Ton. Jenis kepiting yang banyak ditemukan di Merauke adalah Scylla serrata dan Scylla olivacea. Kepiting Scylla serrata oleh masyarakat di Merauke disebut kepiting tentara atau kepiting hijau dan Scylla olivacea disebut sebagai kepiting merah karena warna capitnya yang cenderung orange kemerahan. Menurut Padate et al, (2013) kepiting ini mempunyai warna merah kecoklatan ataupun hitam kecoklatan tergantung habitat hidupnya.

Penangkapan kepiting Merauke masih bersifat tradisional namun intensif dilakukan karena meningkatnya jumlah permintaan pasar. Berdasarkan data Stasiun Karantina Ikan Merauke, terjadi peningkatan pengiriman kepiting dari 99.290 ekor tahun 2014 menjadi 308.061 ekor pada Oktober tahun 2018. Semakin meningkatnya permintaan akan semakin meningkatkan upaya penangkapan di alam yang akan memberikan pengaruh pada populasi kepiting (Sentosa \& Syam, 2011). Populasi kepiting dapat menurun dan mengalami kepunahan sehingga diperlukan upaya pengelolaan yang berkelanjutan untuk menjaga kelestarian sumberdaya kepiting bakau di perairan Merauke. Pengelolaan yang dilakukan memerlukan informasi hasil penelitian tentang dinamika populasi dan tingkat pemanfaatan kepiting tersebut. Perhitungan dinamika populasi menjadi dasar untuk pengelolan perikanan secara efektif (Gulland, 1983).

Informasi tentang kondisi hutan mangrove di Merauke banyak ditemukan namun informasi tentang kondisi kepiting bakau Scylla olivacea masih minim. Tulisan ini akan membahas tentang dinamika populasi : yaitu struktur ukuran, hubungan lebar karapas (WD) dengan bobot tubuh, nisbah kelamin dan rata-rata ukuran pertama kali tertangkap serta tingkat pemanfaatan kepiting Scylla olivacea khususnya di perairan Merauke. Hasil penelitian diharapkan menjadi dasar dalam pengkajian stok sumberdaya kepiting bakau Scylla olivacea dan selanjutnya untuk pengeloaan sumber daya tersebut secara berkelanjutan.

\section{BAHAN DAN METODE Pegumpulan Data}

Penelitian dilakukan di perairan Merauke dan sekitarnya (Gambar 1) selama 2 (dua) tahun yaitu Februari hingga Desember 2017 dan Maret hingga Desember 2018 dengan metode survey. Kegiatan pengumpulan data dilakukan secara bulanan pada tempat pengumpul kepiting dengan bantuan enumerator. Pengukuran sampel dilakukan pada 4.012 ekor tahun 2017 dan 3.309 ekor tahun 2018. Kegiatan pengukuran lebar karapas kepiting dilakukan dengan menggunakan timbangan digital dengan ketelitian 0,01 gram dan jangka sorong (kalifer) dengan ketelitian 0,01 mm. Aspek biologi kepiting bakau yang diamati adalah lebar karapas, bobot dan rasio kelamin yang akan digunakan untuk menetukan beberapa parameter dinamika populasi. Untuk data produksi kepiting diperoleh dari pendataan di pengumpul yaitu jumlah total produksi yang didaratkan setiap bulannya untuk dapat memperkirakan musim penangkapan kepiting. 


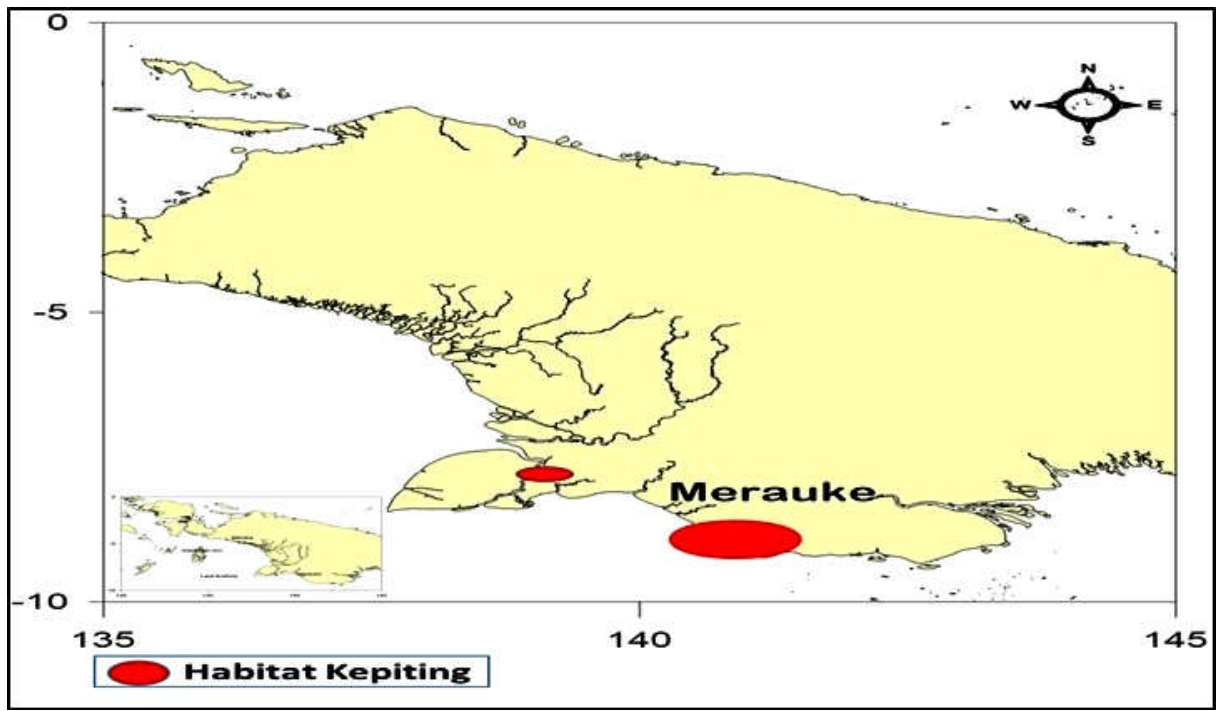

Gambar 1. Lokasi sampling dan daerah penangkapan kepiting merah di perairan Merauke dan sekitarnya. Figure 1. Sampling site and fishing ground Red Mud Crab in Merauke waters and adjacent.

Hubungan lebar karapas dan bobot tubuh mengikuti persamaan (Ball \& Rao, 1984) yaitu :

$\mathrm{W}=\mathrm{a} C \mathrm{~W}^{\mathrm{b}}$

\section{dimana:}

$\mathrm{W}=$ bobot tubuh kepiting (gram),

$\mathrm{CW}=$ panjang karapas kepiting (Carapace width) $(\mathrm{mm})$,

$\mathrm{a}=$ konstanta

$\mathrm{b}=$ nilai eksponensial.

Struktur ukuran kepiting yang diperoleh secara bulanan ditabulasi dan dianalisis sebagai ukuran pertama kali tertangkap (width at first capture, CWc). Selanjutnya dibentuk grafik hubungan antara distribusi kelas lebar karapas (sumbu $\mathrm{x}$ ) dengan persentase kumulatif jumlah kepiting (sumbu y), sehingga terbentuk kurva berbentuk S (sigmoid). Nilai CWc dinyatakan sebagai titik potong antara kurva $50 \%$ frekuensi kumulatif dengan nilai lebar karapas (Saputra et al., 2009).

Parameter pertumbuhan ( $\mathrm{K}$ dan $\mathrm{CW}_{\infty}$ ) ditentukan dengan metode ELEFAN (Gayanilo et al., 1993). Laju kematian total ( $Z$ ) diduga dengan metode kurva hasil tangkapan (catch cuve) yang merupakan slope (b) antara Ln N/t dengan umur relatif (Sparre \& Venema, 1999), sesuai dengan rumus sebagai berikut :

$\operatorname{Ln} \mathrm{N} / \mathrm{t}=\mathrm{a}-\mathrm{Zt}$

dimana :

$\mathrm{N}$ = banyaknya kepiting pada waktu $\mathrm{t}$

$\mathrm{t}=$ waktu yang diperlukan untuk tumbuh suatu kelas panjang $\mathrm{a}=$ hasil tangkapan yang dikonversikan terhadap panjang

Selanjutnya pendugaan umur teoritis pada saat lebar kepiting bakau sama dengan nol (to) digunakan rumus empiris Pauly (1980) sebagai berikut:

$\log \left(-t_{0}\right)=-0,3922-0,2752 \log \left(C W_{\infty}\right)-1,308 \log$

$$
(\mathrm{K}) \text {... }
$$

dimana :

$\mathrm{L}_{\infty}=$ Lebar asimptot kepiting bakau $(\mathrm{mm})$

$\mathrm{K}=$ Koefisien laju pertumbuhan (per tahun)

to = Umur teoritis kepiting bakau pada saat lebar nya sama dengan nol (tahun)

Pendugaan kematian alamiah kepiting dilakukan dengan menggunakan rumus empiris Pauly (1980) sebagai berikut :

Ln $M=-0,152-\left(0,279 \operatorname{Ln} L_{\infty}\right)+(0,6543 \operatorname{Ln} K)+$ $(0,4534$ Ln T.

dimana :

$M=$ laju kematian alamiah

$\mathrm{L}=$ lebar karapas maksimun $(\mathrm{mm})$

$\mathrm{K}=$ laju pertumbuhan $(\mathrm{mm} /$ tahun)

$\mathrm{T}=\operatorname{suhu}\left({ }^{\circ} \mathrm{C}\right)$

Nilai laju kematian karena penangkapan dapat diperoleh dengan menggunakan laju kematian total (Z) dengan laju kematian alamiah $(\mathrm{M})$ atau $\mathrm{F}=\mathrm{Z}-\mathrm{M}$ dan laju pengusahaan $(E)$ dihitung sebagai $E=F / Z$ (Sparre \& Venema, 1999). 


\section{HASIL DAN BAHASAN}

Hasil

\section{Struktur Ukuran}

Sebaran ukuran lebar karapas kepiting merah di Merauke pada tahun 2017 antara 80 - 165 mm yang berukuran lebih besar daripada tahun 2018 yaitu 70 $160 \mathrm{~mm}$. Hal ini dapat dilihat pada April dan Mei 2017 lebih besar dari pada periode yang sama tahun 2018 (105 mm > $120 \mathrm{~mm}$ ), Agustus (120 mm > $125 \mathrm{~mm}$ ) dan Oktober sampai Desember $(130 \mathrm{~mm}>115 \mathrm{~mm})$ (Tabel 1). Namun, secara umum struktur ukuran lebar karapas kepiting merah dominan pada $120 \mathrm{~mm}$.

Tabel 1. Nilai Kisaran dan dominan lebar karapas kepiting merah (Scylla olivacea) di Merauke pada tahun 2017 dan 2018

Table 1. Range of value and dominan width of Mud Crab (Scylla olivacea) in Merauke 2017 and 2018

\begin{tabular}{ccccc}
\hline Tahun/ & \multicolumn{2}{c}{2017} & \multicolumn{2}{c}{2018} \\
\cline { 2 - 5 } Bulan & Kisaran $(\mathbf{m m})$ & Dominan $(\mathbf{m m})$ & Kisaran $(\mathbf{m m})$ & Dominan $(\mathbf{m m})$ \\
\hline Feb & $100-160$ & 120,125 & & \\
Maret & $80-150$ & 120 & $85-150$ & 120 \\
April & $85-165$ & 105 & $100-135$ & 125 \\
Mei & $85-165$ & 105 & $70-140$ & 120 \\
Jun & $85-140$ & 105,115 & $70-125$ & 110 \\
Jul & $90-140$ & 115 & $85-135$ & 115 \\
Agust & $90-150$ & 120 & $85-135$ & 115 \\
Sept & $90-150$ & 120 & $85-135$ & 125 \\
Okt & $90-140$ & 130 & $90-140$ & 125 \\
Nop & $90-140$ & 120 & $75-155$ & 115 \\
Des & $90-140$ & 130 & $80-160$ & 120 \\
\hline
\end{tabular}

Sebaran ukuran lebar karapas kepiting pada tahun 2017 antara jantan dan betina dari $80-165 \mathrm{~mm}$ dengan $99.4 \%$ ditemukan pada ukuran $80-145 \mathrm{~mm}$, sedangkan lainnya menyebar antara $150-165 \mathrm{~mm}$.
Kepiting jantan pada tahun 2018 berukuran $70-160$ $\mathrm{mm}$ dan kepiting betina berukuran 75 - $135 \mathrm{~mm}$ dengan dominan 99,7 \% pada ukuran $70-140 \mathrm{~mm}$ (Gambar 2a dan Gambar 2b).

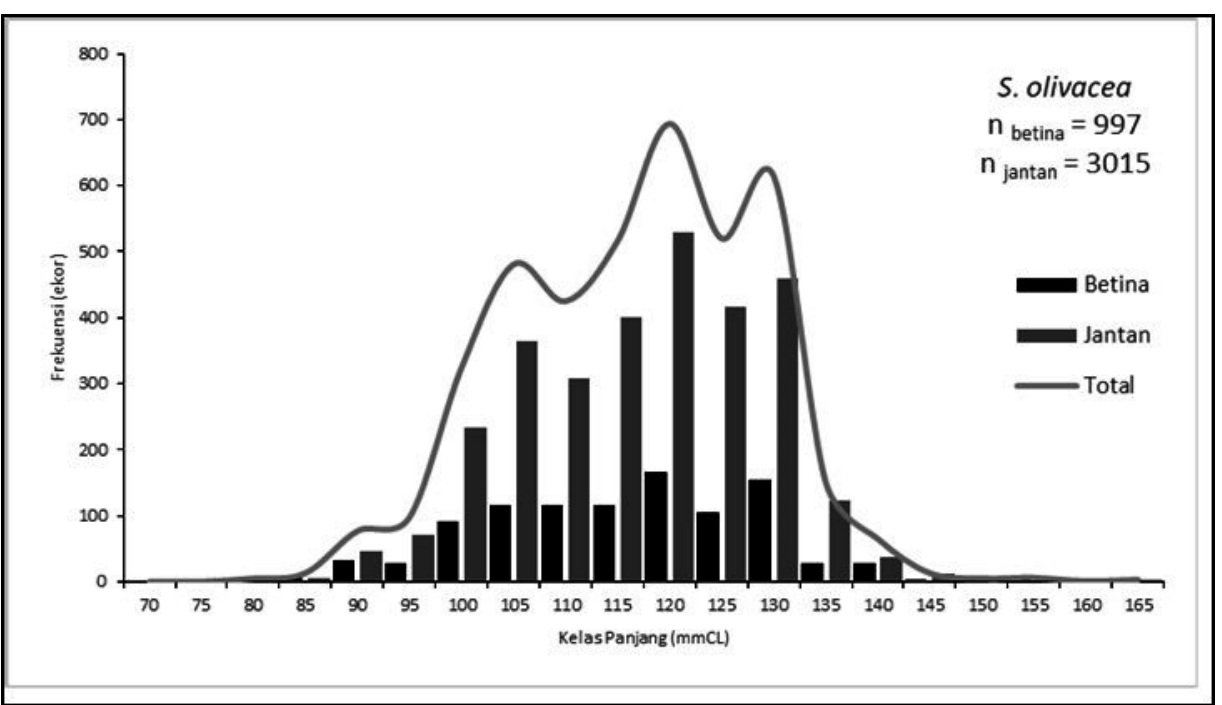

Gambar 2a. Struktur ukuran kepiting merah (S.olivacea) di perairan Kabupaten Merauke dan sekitarnya tahun 2017.

Figure 2a. Size structure of mud crabs (S. olivacea) in Merauke and its adjacent waters, 2017. 


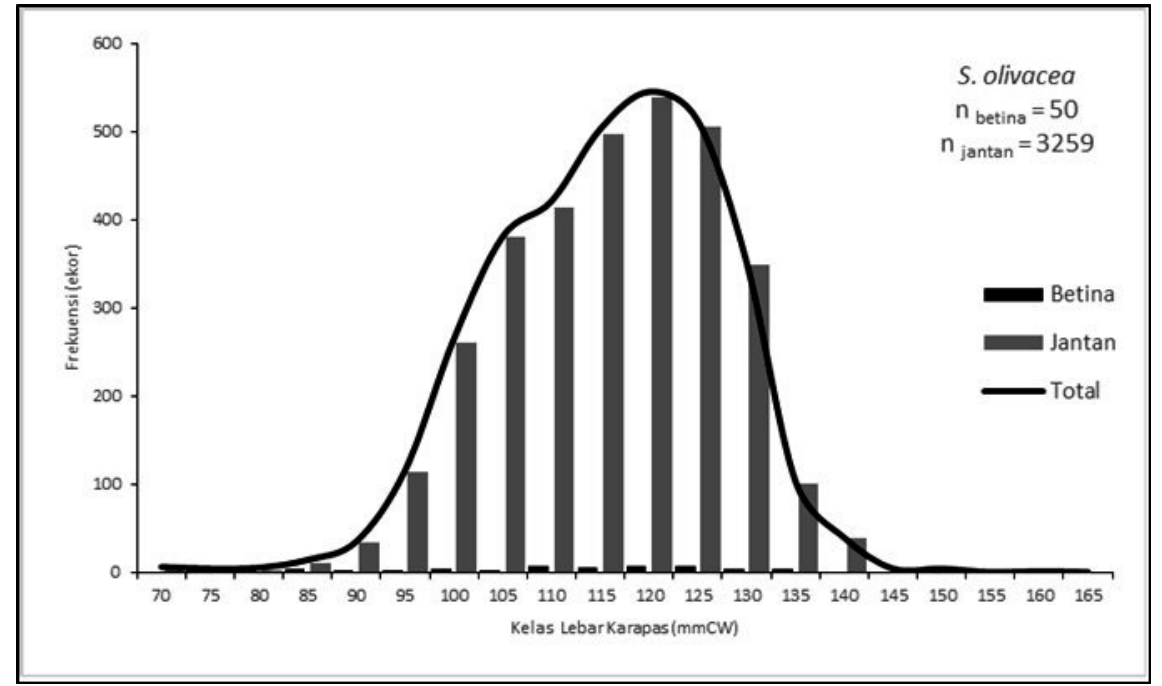

Gambar 2b. Struktur ukuran kepiting merah (S.olivacea) di perairan Kabupaten Merauke dan sekitarnya tahun 2018.

Figure 2b. $\quad$ Size structure of mud crabs (S. olivacea) in Merauke and its adjacent waters, 2018.

Hubungan Lebar Karapas dan Bobot Tubuh, Nisbah Kelamin serta Rata-rata Ukuran Pertama Kali Tertangkap

Hubungan lebar karapas dengan bobot tubuh kepiting merah di perairan ini menunjukkan pola pertumbuhan kepiting jantan dan betina bersifat allometrik negatif yang diindikasikan oleh nilai $b$ kurang dari 3 , kecuali pada kepiting betina tahun 2018 yang bersifat allometrik positif b lebih dari 3 (Tabel 2).

Nisbah kelamin antara kepiting merah betina dengan jantan berdasarkan uji Chi-kuadrat tidak seimbang (Tabel 3).

Tabel 2. Hubungan lebar karapas dan bobot kepiting merah di Merauke

Tabel 2. Carapace Width-weight relationship of red mud crabs in Merauke

\begin{tabular}{|c|c|c|c|c|}
\hline \multirow{2}{*}{$\underline{\text { Tahun/Jenis }}$} & \multicolumn{3}{|c|}{ Nilai Konstanta Regresi } & \multirow{2}{*}{ Sifat Pertumbuhan } \\
\hline & $\mathbf{a}$ & b & $\mathbf{R}^{2}$ & \\
\hline 2017 & & & & \\
\hline Betina & 0,0105 & 2,1537 & 0,8369 & Allometrik Negatif \\
\hline Jantan & 0,0066 & 2,2494 & 0,999 & Allometrik Negatif \\
\hline Gabungan & 0,0076 & 2,2192 & 0,9467 & Allometrik Negatif \\
\hline \multicolumn{5}{|l|}{2018} \\
\hline Betina & 0,0001 & 3,1037 & 0,847 & Allometrik Positif \\
\hline Jantan & 0,0021 & 2,5445 & 0,6889 & Allometrik Negatif \\
\hline Gabungan & 0,0018 & 2,5733 & 0,6931 & Allometrik Negatif \\
\hline
\end{tabular}

Tabel 3. Nisbah Kelamin Kepiting Merah (Scylla olivacea)

Tabel 3. Sex ratio red mud crab (Scylla olivacea)

\begin{tabular}{ccccc}
\hline \multirow{2}{*}{ Tahun } & \multicolumn{2}{c}{ Jenis Kelamin } & \multicolumn{2}{c}{ Nisbah Kelamin } \\
\cline { 2 - 5 } & Betina (Ekor) & Jantan (Ekor) & Betina & Jantan \\
\hline $\mathbf{2 0 1 7}$ & 997 & 3.015 & 1 & 3 \\
$\mathbf{2 0 1 8}$ & 50 & 3.259 & 1 & 65 \\
\hline
\end{tabular}

Berdasarkan analisa struktur ukuran yang diperoleh dilapangan maka ukuran pertama kali tertangkap (CWc) kepiting merah di perairan Merauke dan sekitarnya adalah $110,52 \mathrm{~mm}$ (2017) dan 112,5 $\mathrm{mm}$ (2018) yang artinya kepiting yang pertama kali tertangkap ukurannya semakin besar (Gambar 3). 


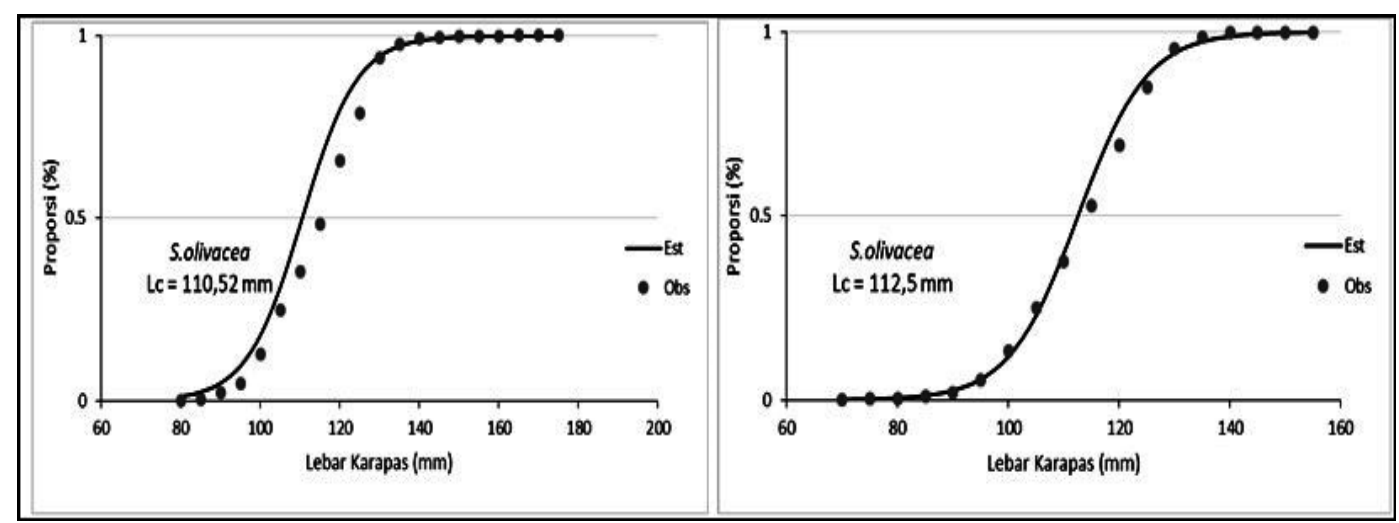

Gambar 3. Ukuran pertama kali tertangkap (CWc) Scylla olivacea Merauke (a) Tahun 2017, (b) Tahun 2018. Figure 3. CWc of red mud crabs (S. olivacea) in Merauke (a) 2017, (b) 2018.

\section{Laju Pertumbuhan, Laju Kematian dan Tingkat Pemanfaatan}

Nilai laju pertumbuhan $(K)$ dan lebar karapas maksimum (CWoo) kepiting merah di perairan Merauke dan sekitarnya pada tahun 2017 mengikuti persamaan $\mathrm{Lt}=\mathbf{1 1 0 , 5 2}\left[1-\mathrm{e}^{-1,08(t-0,009)}\right]$ dan tahun 2018 $\mathrm{Lt}=112,5\left[1-\mathrm{e}^{-0,95(\mathrm{t}-0,694)}\right]$. Tingkat pemanfaatan $(\mathrm{E})$ kepiting merah pada 2017 dan 2018 sebesar 0,68 per tahun. Nilai ini menunjukkan pemanfaatan kepiting merah di perairan ini sudah lebih tangkap (overfishing).

\section{Bahasan}

Pola sebaran ukuran kepiting betina dan jantan pada 2017 dan 2018 cenderung sama yaitu $80-165$ $\mathrm{mm}$ dan dan $70-160 \mathrm{~mm}$ (2018) Kurang dari $1 \%$ betina dan jantan yang ditemukan berukuran $<145$ $\mathrm{mm}$. Perbandingan struktur ukuran berdasarkan penelitian di berbagai perairan terlihat kepiting merah di Merauke berukuran lebih besar daripada diperairan lainnya (Tabel 5).

Tabel 4. Nilai Parameter Populasi Kepiting Merah di Perairan Merauke dan Sekitarnya pada tahun 2017 2018

Tabel 4. Population parameters of red mud crabs in Merauke waters in 2017-2018

\begin{tabular}{|c|c|c|c|}
\hline \multirow[b]{2}{*}{ Parameter } & \multirow[b]{2}{*}{ Satuan } & \multicolumn{2}{|c|}{ Nilai } \\
\hline & & 2017 & 2018 \\
\hline $\begin{array}{l}\text { Ukuran pertama kali tertangkap } \\
\text { (CWc) }\end{array}$ & $\mathrm{mm}$ & 110,52 & 112,5 \\
\hline Lebar karapas maksimum $\left(\mathrm{CW}_{\infty}\right)$ & tahun & 171,75 & 162,65 \\
\hline Laju pertumbuhan (K) & tahun & 0,6 & 0,6 \\
\hline $\begin{array}{l}\text { Umur pada saat lebar sama dengan } \\
\text { nol }\left(t_{0}\right)\end{array}$ & tahun & $-1,11428$ & $-1,13001$ \\
\hline Kematian total (Z) & tahun & 2,52 & 2,53 \\
\hline Kematian Alamiah (M) & tahun & 0,8 & 0,81 \\
\hline Kematian penangkapan (F) & tahun & 1,72 & 1,72 \\
\hline Tingkat pemanfaatan $€$ & tahun & 0,68 & 0,68 \\
\hline
\end{tabular}

Tabel 5. Struktur ukuran kepiting merah (Scylla olivacea) di berbagai perairan

Table 5. Size strukcture red mud crab (Scylla olivacea) in some water area

\begin{tabular}{|c|c|c|c|}
\hline No & Lokasi & Struktur Ukuran & Sumber \\
\hline 1 & $\begin{array}{l}\text { Ranong Magrove, } \\
\text { Thailand }\end{array}$ & $50-135 \mathrm{~mm}$ & Moser et al., 2005 \\
\hline 2 & Thailand & $\begin{array}{l}40-155 \mathrm{~mm} \text { (jantan) } \\
40-140 \mathrm{~mm} \text { (betina) }\end{array}$ & Jirapunpiat, 2008 \\
\hline 3 & Tapanuli Tengah & $90-116,1 \mathrm{~mm}$ & Larosa et al., 2013 \\
\hline 4 & Semarang & $47,05-132,56 \mathrm{~mm}$ & Hardiyanti et al., 2018 \\
\hline
\end{tabular}


Pola pertumbuhan kepiting merah yang bersifat allometrik negatif menunjukan bahwa pertumbuhan lebar tubuh lebih cepat dibanding pertumbuhan bobotnya. Pada kepiting betina ada yang bersifat allometrik positifyang artinya pertambahan bobotnya lebih lambat daripada pertambahan lebar karapas. Perbedaan sifat pertumbuhan tersebut dapat terjadi karena makanan dan dikarenakan kepiting betina membawa gonad dalam tubuhnya. Makanan kepiting merah Scylla olivacea di perairan India yang dominan adalah krustasea dan moluska baik kepiting jantan maupun betina (Viswanathan \& Raffi, 2015). Mangrove yang mempunyai tutupan yang tinggi menghasilkan serasah yang banyak, menjadi sumber makanan makrozoobentos sehingga kepiting mempunyai cukup makanan untuk pertumbuhan karapas dan bobot tubuh kepiting bakau (Tahmid et al., 2015b; Yulianti \& Sofiana, 2018).

Nisbah kelamin kepiting merah di perairan Merauke menunjukkan kondisi tidak seimbang, dimana kepiting jantan lebih dominan, bahkan pada tahun 2018 selama penelitian hanya ditemukan 50 ekor kepiting betina. Penyebab terjadinya ketidakseimbangan tersebut dikarenakan kepiting betina yang sudah berkurang nilai jualnya sehingga hanya dipasarkan secara lokal. Nelayan dominan tidak lagi menangkap kepiting betina dan jika tertangkap betina langsung dipasarkan di sekitar desa tempat menangkap. Nisbah kelamin dominan jantan ini sejalan dengan studi Jirapunpipat (2008) di Thailand dimana perbandingan betina dengan jantan $1: 1,3$, di Serawak Malaysia 0,89: 1 (Ikhwanuddin et al., 2011) dan di perairan Eretan Indramayu 1:1,5 (Sunarto et al., 2015). Banyak hal yang menjadi penyebab perbedaan nisbah kelamin baik karena penangkapan maupun karena faktor migrasi kepiting (Suman, 2004; Edrus \& Syam, 2004). Kepiting betina akan melakukan migrasi ke laut untuk melakukan kegiatan pemijahan sedangkan kepiting jantan tetap berada di hutan mangrove (Hill, 1975). Sementara secara umum nelayan kepiting di Merauke yang dominan perempuan memang melakukan kegiatan penangkapan hanya di hutan mangrove pinggiran. Alat penangkap kepiting yang digunakan adalah pengait dan beberapa nelayan yang menggunakan jaring.

Kepiting pertama kali tertangkap (CWc) pada penelitian ini mempunyai lebar karapas $110,52 \mathrm{~mm}$ (2017) dan meningkat pada tahun 2018 sebesar 112,5 $\mathrm{mm}$ yang menunjukkan bahwa kepiting yang tertangkap semakin besar ukurannya. Namun demikian ukuran tersebut masih dibawah ukuran yang ditetapkan dalam Peraturan Menteri Kelautan dan Perikanan Nomor 56/ PERMEN - KP/ 2016 sebesar $15 \mathrm{~cm}$.
Struktur ukuran kepiting memberikan pengaruh pada analisa nilai koefiesin pertumbuhan (K). Nilai koefisen pertumbuhan $(K)$ itu menunjukkan tingkat waktu yang diperlukan individu untuk mencapai panjang asimtotiknya (Sparre \& Venema, 1999). Jika nilai koefisen pertumbuhan $(\mathrm{K})$ semakin rendah maka individu tersebut semakin lama membutuhkan waktu untuk mencapai panjang asimtotiknya dan sebaliknya. Nilai laju pertumbuhan (K) kepiting merah di Merauke adalah 0,60 per yang menunjukan bahwa laju pertumbuhannya tergolong cepat mencapai panjang asimtotiknya. Kepiting yang mempunyai nilai $\mathrm{K}$ tinggi akan semakin cepat pertumbuhannya dan akan mempercepat kepiting mencapai ukuran dewasa dan menambah jumlah populasi.

Nilai lebar karapas maksimum $\left(\mathrm{CW}_{\infty}\right)$ kepiting merah mengalami penurunan dari $171,75 \mathrm{~mm}$ (2017) menjadi 162,65 mm (2018). Penyebab nilai koefisen pertumbuhan $(\mathrm{K})$ dan nilai lebar karapas maksimun $\left(\mathrm{CW}_{\infty}\right)$ disebabkan oleh adanya perbedaan kelimpahan makanan, kondisi lingkungan serta struktur ukuran kepiting yang dianalisis. Populasi kepiting juga dipengaruhi faktor fisika dan kimia lingkungan habitat hidupnya. Suhu, salinitas dan tingkat keasaman $(\mathrm{pH})$ memberikan pengaruh bagi kelangsungan hidup kepiting (Karim et al., 2015). Kepiting merah di Merauke dapat berkembang dengan baik karena suhu perairan nya adalah $26-32^{\circ} \mathrm{C}$, salinitasnya 17 - 22 promil dan tingkat keasaman (pH) 7,6 - 8,9 (Lantang \& Pakidi, 2015). Ini sejalan dengan yang dinyatakan oleh Cholik (2005) suhu yang cocok bagi kepiting bakau adalah $18^{\circ} \mathrm{C}-35^{\circ} \mathrm{C}$, tingkat keasaman (pH) 6,5-7,5 (Siahainenia, 2008) dan 7,33 - 8,23 (Karim et al., 2015). Salinitas di perairan ini sesuai untuk kepiting merah yang menyenangi habitat hidup dengan salinitas yang lebih rendah yaitu $21-22$ promil daripada Scylla serrata yang tolerasi terhadap salinitas $>28$ promil (Avianto et al., 2013) dan substrat yang lebih padat (Sunarto et al., 2015).

Kematian alamiah kepiting di Merauke adalah 0,8 - 0,81 per tahun yang sama dengan di Ranong, Thailand senilai 0,49-1 per tahun (Moset et al, 2005). Kematian alamiah yang tinggi di Merauke bisa disebabkan oleh penurunan kualitas hutan mangrove yang sudah mulai mengalami kerusakan seperti di daerah Samkai, Merauke (Masiyah \& Monika, 2017). Namun, analisa nilai kematian total (M) kepiting merah di perairan ini masih lebih rendah dibandingkan nilai kematian karena kegiatan penangkapan $(F)$ yaitu 1,72 per tahun. Maka kepiting di Merauke sebagian besar mati karena upaya penangkapan. Meningkatnya nilai kematian karena penangkapan menunjukkan bahwa upaya pemanfatan kepiting sudah semakin meningkat 
dari tahun ke tahun. Permintaan pasar akan kepiting menyebabkan usaha penangkapan menjadi intensif dilakukan nelayan.

Tingkat pemanfaatan kepiting Scylla olivacea di perairan Merauke dan sekitarnya tahun 2017 dan 2018 yaitu $\mathrm{E}=0,68$ yang menunjukkan sudah over fishing sesuai Pauly et al, (1984). Tingkat pemanfatan kepiting merah di Merauke sudah mencapai $136 \%$ sehingga harus dilakukan pengurangan upaya sebanyak $36 \%$ dari upaya yang telah dilakukan saat ini. Pengurangan upaya penangkapan kepiting juga harus diikuti oleh perbaikan habitat kepiting yaitu hutan mangrove karena penurunan luasan, rendahnya tingkat kerapatan dan aktivitas manusia seperti penebangan pohon mangrove menyebabkan penurunan kelestarian hutan mangrove. Menurut Siahainenia (2008) serta Sentosa \& Syam (2011) bahwa terjadinya degradasi ekosistem mangrove dan eksploitasi berlebihan akan menurunkan populasi kepiting bakau (Scylla sp.). Menjaga populasi kepiting maka harus turut serta menjaga habitat lingkungan hidupnya yaitu hutan mangrove karena kepiting berasosiasi dengan mangrove yang kondisinya baik dan kerapatannya serta bahan organik yang tinggi (Wijaya et al., 2010; Serosero, 2011; Yulianti \& Sofiana, 2018).

Berdasarkan data WWF tahun 2010 dalam Widiastuti et al, (2016) bahwa luas hutan mangrove di Merauke hanya sekitar 296.778 Ha dengan kerapatan hanya 348 pohon/ $\mathrm{Ha}$, kerusakan hutan mangrove di Samkai sepanjang 1,5 km dengan luasan mangrove lebih kurang $2 \mathrm{Ha}$ serta di pesisir Lampu Satu yang rusak akibat gelombang pasang yang tinggi (Masiyah \& Monika, 2017) menjadi indikasi penurunan kuantitas dan kualitas mangrove sebagai habitat kepiting merah. Saleh (2004) menyatakan bahwa mangrove berfungsi sebagai daerah asuhan dan tempat peminjahan ikan, namun keterbatasan pemahaman dapat menyebabkan kerusakan ekosistem mangrove dan mengabaikan keseimbangan ekologi (Lasibani \& Kamal, 2010). Suryani (2006) menyatakan bahwa melakukan pengawasan ekosisitem mangrove dengan meningkatkan pengetahuan masyarakat tentang habitat kepiting serta larangan untuk menangkap kepiting betina dan kepiting berukuran kecil tersebut menjadi salah satu dasar pengelolaan kelestarian kepiting. Ekosistem mangrove tidak hanya sebagai habitat hidup kepiting dewasa namun proses pemijahan (spawning ground), daerah asuhan (nursery ground) dan tempat mencari makan (feeding ground) (Sunarto et al., 2015). Namun meningkatkan pemahaman masyarakat tentang pentingnya hutan mangrove tidak dapat dilakukan hanya satu pihak namun melibatkan pihak lain seperti organisasi masyarakat, pemerintah daerah dan pihak swasta.

\section{KESIMPULAN}

Struktur ukuran kepiting merah (Scylla olivacea) dari tahun 2017 sampai dengan tahun 2018 adalah 70 - $165 \mathrm{~mm}$ dengan pola pertumbuhan dominan allometrik negatif. Ukuran rata-rata pertama kali tertangkap (CWc) semakin meningkat. Tingkat pemanfaatan sumber daya kepiting sudah berada pada tahapan tangkapan yang berlebih (overfishing) terkait dengan penangkapan yang tradisional namun intensif. Untuk menjamin kelestarian sumber daya kepiting di perairan Merauke dan sekitarnya, perlu dilakukan pengurangan upaya penangkapan sebesar $36 \%$ dan perbaikan ekosistem mangrove di Merauke yang semakin menurun jumlah dan kualitasnya. Pengurangan upaya penangkapan dan perbaikan ekosistem mangrove memerlukan pihak selain masyarakat yaitu Pemerintah Daerah dan pihak swasta.

\section{PERSANTUNAN}

Tulisan ini merupakan kontribusi dari kegiatan Penelitian Karakteristik Biologi Perikanan, Habitat Sumberdaya, dan Potensi Produksi Sumberdaya Ikan di WPP 718 Laut Arafura Tahun Anggaran 2017 dan 2018 pada Balai Riset Perikanan Laut, Cibinong Bogor. Penulis mengucapkan terima kasih kepada Drs. Suprapto dan Prof Ali Suman sebagai Penanggung jawab kegiatan penelitian WPP 718 Tahun 2017 dan 2018 serta tenaga enumerator untuk sumberdaya kepiting di Merauke yaitu Bapak Mizwar S.Pi.

\section{DAFTAR PUSTAKA}

Avianto, Irvan., Sulistiono., \& Setyobudiandi, I. (2013). Karateristik habitat dan potensi kepiting bakau (Scylla serrata, S. transquaberica and S. olivacea) di Hutan Mangrove Cibako, Sancang, Kabupaten Garut Jawa Barat. Aquasains. 2(1), 97-106.

Ball, D,V., \& Rao, K, V. (1984). "Marine Fisheries." New Delhil : Tata Mc. Graw-Hill Publishing Company Limited., p. 5-24.

Cholik, F. (2005). Review of mud crab culture research in Indonesia, Central Research Institute for Fisheries, PO Box 6650 Slipi, Jakarta, Indonesia, 310CRA.

Diantoro, G., \& Pribadi, R. (2017). Analisa interaksi antar tropic level pada populasi kepiting (Scylla olivacea) di Kawasan Muara Sungai Cenrana, Kabupaten Bone. Prosiding Simposium Nasional Krustasea 2017. 85-96. 
Dinas Lingkungan Hidup Propinsi Papua. (2018). Data Luas Hutan Mangrove Menurut Kabupaten/ Kota di Papua Tahun 2010. Website www.lingkunganhidup.papua.go.id. Diakses pada 30 Januari 2018 pukul 9.02 Wib.

Edrus, I, N., \& Syam, A.R. (2004). Analisis hasil tangkapan rakang dan bubu pada percobaan penangkapan kepiting di Perairan Mangrove Maluku. J.Lit.Perikan.Ind,10(4), 77 - 86. DOI: http://dx.doi.org/10.15578/jppi.10.4.2004.7786

Gayanilo, F. C. Jr, Sparre, P., \& Pauly, D. (1993). The FISAT user's guide. FAO Computerized Information Series Fisheries. ICLARM - DIFMAR.

Gulland, J. A. (1983). Fish stock assessment (p. 223). A manual of basic methods. John Wiley and Sons. NewYork.

Hardiyanti, A, S., Sunaryo., Riniatsih, I., \& Santoso, A. (2018). Biomorformetrik kepiting bakau (Scylla sp.) Hasil Tangkapan di Perairan Semarang. Buletin Oseanografi Marina. 7 (2), 81 - 90. DOI: https://doi.org/10.14710/buloma.v7i2.20686

Herliany, N,E., \& Zamdial. (2015). Hubungan lebar karapas dan berat kepiting bakau (Scylla spp) Hasil Tangkapan di Desa Kahyapu Pulau Enggano Provinsi Bengkulu. Jurnal Kelautan. 8 (2): 89 94. DOI: http://dx.doi.org/10.21107/jk.v8i2.818

Hill, B. J. (1975). Abundance, breeding and growth of the crab Scylla serrata in two South African estuaries. Marine Biology. 32, 119-126.

Ikhwanuddin, M., Azmie, G., Juariah, H, M., Zakaria, M. Z., \& Ambak, M. A. (2011). Abstrak biological information and population features of mud crab, genus scylla from mangrove areas of Sarawak, Malaysia. Fisheries Research. 108 (2-3), 299 306. Diakses pada https:// www.sciencedirect.com/science/article/abs/pii/ S0165783611000038 tanggal 16 Januari 2018 Pukul 13.44 Wib.

Jirapunpipat, K. (2008). Population structure and size maturity of the orange mud crab Scylla olivacea in Klong Ngao mangrove Swamp Ranong Propince, Thailand. Kasetsart Journal. Natural Science. 42, 31-40.

Karim, M. Y. (2008). Pengaruh salinitas terhadap metabolisme kepiting bakau (Scylla olivacea).
Jurnal Perikanan. X (1), 37-44. DOI: https://doi.org/10.22146/jfs.8926

Karim, M, Y., Zainuudin., \& Aslamsyah, S. (2015). Pengaruh suhu terhadap kelangsungan hidup dan percepatan metamorfosisi larva kepiting bakau (Scylla olivacea). Jurnal Perikanan. XVII (2), 84 89. DOI : https://doi.org/10.22146/jfs. 10370

Keenan, C.P., Davie, P.J.F., \& Mann, D.L. (1998). A revision of the genus Scylla De HAAN, 1983 (Crustacea: Decapoda: Brachyura: Portunidae). The Raffles Bulletin of Zoology, 46 (1), 217-245.

Lantang, B \& Pakidi, C, S. (2015). Identifikasi jenis dan pengaruh faktor oseanografi terhadap fitoplankton di perairan Pantai Payum - Pantai Lampu Satu Kabupaten Merauke. Jurnal IImiah Agribisnis dan Perikanan (Agrikan UMMU - Ternate). 8 (2),13-19.DOI: https://doi.org/10.29239/ j.agrikan.8.2.13-19

Lasibani, S, M., \& Kamal, E. (2010). Pola penyebaran pertumbuhan "propagul" mangrove rhizophoraceae di kawasan pesisir Sumatera Barat. Jurnal Mangrove dan Pesisir. X (1), $33-38$.

La Sara. (2010). Study on the size structure and population parameters of mud crab Scylla serrata in Lawele Bay, Southeast Sulawesi, Indonesia. Journal of Coastal Development. 13(2), 133-147.

Larosa, R., Hendrarto, B \& Nitisupardjo, M. (2013). Identifikasi Sumberdaya Kepiting Bakau (Scylla sp) yang Didaratkan di TPI Kabupaten Tapanuli Tengah. Journal of Management of Aquatic Resource. 2 (3), $180-189$.

Le Vay, L. (2001). Ecology and stock assessment of Scylla spp. In: Proceedings of the International Forum on the Culture of Portunid Crabs, Boracay, Philippines, December, 14, 101-111.

Masiyah, S., \& Sunarni. (2015). Komposisi jenis dan kerapatan mangrove di pesisir arafura kabupaten merauke Propinsi Papua. Jurnal IImiah Agribisnis dan Perikanan (Agrikan UMMU - Ternate). 8 (1), 60 - 68. DOI: https://doi.org/10.29239/ j.agrikan.8.1.60-68

Masiyah, S., \& Arifin, T. (2016). Kondisi dan jenis mangrove di Kabupaten Merauke, Propinsi Papua. Jurnal IImiah Agribisnis dan Perikanan (Agrikan UMMU - Ternate). 9 (2), 35 - 40. DOI: https:// doi.org/10.29239/j.agrikan.9.2.34-40 
Masiyah, S. (2016). Biodiversitas mangrove di kabupaten merauke Propinsi Papua. Jurnal IImiah Agribisnis dan Perikanan (Agrikan UMMU - Ternate). 9 (1), 1 - 7. DOI: https://doi.org/10.29239/ j.agrikan.10.1.1-7

Masiyah, S., \& Monika, N. (2017). Analisis ekologi mangrove sebagai dasar rehabilitasi di pesisir Arafura Samkai Distrik Merauke Kabupaten Merauke Propinsi Papua. Jurnal IImiah Agribisnis dan Perikanan (Agrikan UMMU - Ternate). 10 (2), 29 - 35. DOI: https://doi.org/10.29239/ j.agrikan.10.2.29-35

Moser, S., Macintosh, D, J., Laoprasert, S., \& Tongdee N. (2005). Population ecology of the mud crab scylla olivacea: a study in the ranong mangrove ecosystem, thailand, with emphasis on juvenile recuitment and mortality. Fisheries Research. 17 (1), 27 - 41. DOI: https://doi.org/10.1016/ j.fishres.2004.07.008

Nontji, A. (2007). Laut Nusantara. Djambatan.

Padate, V, P., Rivonker, C, U., \& Anil, A, C. (2013). A new record of Scylla olivacea (Decapoda, Bachyura, Prtunidae) from Goa Central West Coast of India - A Comparative Diagnosis. Journal of Geo-Marine Sciences. 42 (1), 82 - 89.

Pauly, D. (1980). A Selection of a simpel methods for the assessment of the tropical fish stock. FAO Fish. Circ. FIRM/ C 729. Roma. 54 pp.

Pauly, D., Ingles, J., \& Neal, R. (1984). Application to shrimp stocks of objective methods for the estimation of growth, mortality and recruitment related parameters from length frequency data (ELEFAN I and II). In : Penaeid shrimp - their biology and management. Fishing News Book Limited. Farnham-Surrey-England, 220-234.

Saleh, A, R., Kamal, E., \& Jati, D, W. (2004). Aplikasi citra satelit terhadap penyebaran ekosistem mangrove kawasan Batang Tomak Air Bangis Pasaman Barat. Jurnal Mangrove dan Pesisir. III (4), 1- 7.

Saputra, S. W., Soedarsono,P. \& Sulistyawati,G.A. (2009). Beberapa aspek biologi ikan kuniran (Upeneus spp.) di Perairan Demak. Jurnal Saintek Perikanan. 5(1), 1-6.

Sentosa, A \& Syam, A. (2011). Sebaran temporal faktor kondisi kepiting bakau (Scylla Serrata) Di Perairan Pantai Mayangan,Kabupaten Subang,
Jawa Barat, Jurnal Perikanan. XIII (1), 34-43. DOI: https://doi.org/10.22146/jfs.3060

Serosero, R. (2011). Karakteristik habitat kepiting bakau (Scylla spp) Di Perairan Pantai Desa Todowongi Kecamatan Jailolo Selatan Kabupaten Halmahera Barat. Jurnal IImiah agribisnis dan Perikanan (agrikan UMMU-Ternate). 4 (1), 69-73. DOI:https://doi.org/10.29239/j.agrikan.4.1.69-73

Siahainenia, L. (2008). bioekologi kepiting bakau (Scylla spp.) di Ekosistem Mangrove Kabupaten Subang Jawa Barat. Disertasi S3. Sekolah Pascasarjana IPB. Bogor.

Sparre, P., \& Venema, S. (1999). Introduction tp tropical fish stock assesment. (Introduksi Pengkajian Stok Ikan Tropis, alih bahasa : Pusat Penelitian dan Pengembangan Perikanan). Buku 1 : Manual. Badan Penelitian dan Pengembangan Perikanan. Jakarta. 438 p.

Suman, A. (2004). Pola pemanfaatan sumber daya udang dogol (Metapenaeus ensis de Haan) di perairan Cilacap dan sekitarnya. Disertasi. Sekolah Pasca Sarjana, IPB, Bogor.

Sunarto., Sulistiono., \& Setyobudiandi, I. (2015). Hubungan jenis kepiting bakau (Scylla spp) dengan Mangrove dan Substrat di Tambak Silvofishery Ereta, Indramayu. Marine Fisheries. 6 (1), 59 68. DOI: https://doi.org/10.29244/jmf.6.1.59-68

Suryani, M. (2006). Ekologi kepiting bakau (Scylla serrata Forskal) dalam ekosistem mangrove di Pulau Enggano Propinsi Bengkulu, Thesis. Program Pascasarjana Universitas Diponegoro. 91 p.

Tahmid, M., Fahrudin, A., \& Wardiatno, Y. (2015a). Kajian struktur ukuran dan parameter populasi kepiting bakau (Scylla serrata) di Ekosisistem Mangrove Teluk Bintan, Kepulauan Riau. Jurnal Biologi Tropis. 15 (2), 93 - 106. DOI: DOI: http:// dx.doi.org/10.29303/jbt.v15i2.192

Tahmid, M., Fahrudin, A., \& Wardiatno, Y. (2015b). Kualitas habitat kepiting bakau (Scylla serrata) pada Ekosisistem Mangrove Teluk Bintan, Kabupaten Bintan, Kepulauan Riau. Jurnal IImu dan Teknologi Kelautan Tropis, 7 (2), 535-551. DOI: https://doi.org/10.29244/jitkt.v7i2.11025

Viswanathan, C \& Raffi, SM. (2015). The Natural Diet $f$ The Mud Crab Scylla olivacea (Herbst, 1896) in Pichavaram mangroves, India. Abstrak in Saudi 
Journal Biological Science. 22 (6), 698 - 705. DOI. 10.1016/j.sjbs.2015.08.005

Waiho, K., Mustaqim, M., Fazhan, H., Norfaizza, W, B, W., Megat, F, H., \& Ikhwanuddin, M. (2015). Mating behaviour of the orange mud crab, scylla olivacea: the effect of sex ratio and stocking density on mating success. Elsevier. Aquaculture Reports. 2, 50 - 57. DOI: https://doi.org/10.1016/ j.aqrep.2015.08.004

Wibisono, G. (2013). Kajian struktur komunitas dan komposisi vegetasi mangrove serta sistem pengelolaannya di Kelurahan Samkai Kabupaten Merauke. Thesis. Program Pascasarjana. Universitas Terbuka. $401 \mathrm{p}$.
Widiastuti, M, M, D., Ruata, N, N., Arifin, T., (2016). Valuasi ekonomi ekosistem mangrove di wilayah pesisir Kabupaten Merauke. Jurnal Sosek KP. 11 (2), 147 - 159. DOI: http://dx.doi.org/10.15578/ jsekp.v11i2.3856

Wijaya N.I., Yulianda F., Boer M., \& Juwana S.(2010). Biologi populasi kepiting bakau (Scylla serrata F.) di Habitat Magrove Taman Nasional Kutai Kabupaten Kutai Timur. Jurnal Oseanografi dan Limnologi di Indonesia. (3), 443-461.

Yulianti \& Sofiana, M, S, J. (2018). Kelimpahan kepiting bakau (Scylla spp) di Kawasan Rehabilitasi Mangrove Sitapuk, Singkawang. Jurnal Laut Kathulistiwa. 1 (1), 25 - 30. 